\title{
Phytochemical and Antinociceptive Investigations of Anemone coronaria Active Part Ameliorating Diabetic Neuropathy Pain
}

\section{(웅ㅇ $\odot$}

Authors

Karim Raafat, Abdalla El-Lakany

Affiliation

Department of Pharmaceutical Sciences, Faculty of

Pharmacy, Beirut Arab University, 115020 Beirut, Lebanon

Key words

Anemone coronaria, Ranunculaceae, diabetic-neuropathy pain, glaucine, in vivo antioxidant, $\mathrm{HbA1c}$

$\begin{array}{ll}\text { received } & 23.01 .2017 \\ \text { revised } & 09.12 .2017 \\ \text { accepted } & 12.12 .2017\end{array}$

Bibliography

DOI https://doi.org/10.1055/s-0044-100148

Planta Med Int Open 2018; 5: e5-e13

(c) Georg Thieme Verlag KG Stuttgart · New York

ISSN 2509-9264

Correspondence

Dr. Karim Raafat

Pharmaceutical Sciences Department

Faculty of Pharmacy

Beirut Arab University (BAU)

115020 Beirut

Lebanon

Tel.: +961/130/0 110, Fax: +961/130/0110 Ext: 2599

karim.raafat@yahoo.com, k.raafat@bau.edu.Ib

Supporting information available online at http:// www.thieme-connect.de/products

\begin{abstract}
Phytochemicals might offer economic therapies, which are an alternative especially for low-income developing countries. Anemone coronaria has been used extensively as antineuralgic and antirheumatic in the folk medicine of Lebanon. Thus, the aim of this study was to investigate the antinociceptive potential of $A$. coronaria and its active principles against diabeticneuropathy pain in a mouse-model. The study also aimed to achieve a bio-guided fractionation and to isolate the most active principles in A. coronaria herb. Bio-guided fractionation used reversed phase-HPLC, and ${ }^{1} \mathrm{H}$ and ${ }^{13} \mathrm{C}$ NMR for the identification of the most active fraction of $A$. coronaria, which was rich in alkaloids. This isolated alkaloid rich fraction contained catalin (21.1\%), thaliporphine (14.1\%), and glaucine (compound 3) (63.4\%). A. coronaria extract $(50,100$, and $200 \mathrm{mg} / \mathrm{kg})$, the isolated alkaloid rich fraction $(70 \mathrm{mg} / \mathrm{kg})$, and glaucine $(25$, 50 , and $100 \mathrm{mg} / \mathrm{kg}$ ) showed significant reduction in acute and subchronic hyperglycemia, with significant increase in glutathione and catalase levels, along with normalization of $\mathrm{HbA} 1 \mathrm{c}$ and LPO levels ( $n=7$ per group, $p \leq 0.05$ ). A. coronaria extract $(50,100$, and $200 \mathrm{mg} / \mathrm{kg})$, the isolated alkaloid rich fraction ( $70 \mathrm{mg} / \mathrm{kg})$, and glaucine $(25,50$, and $100 \mathrm{mg} / \mathrm{kg}$ ) also showed significant antinociceptive amelioration in thermal hyperalgesia pain latencies utilizing hot plate and tail flick tests. The highest doses of $A$. coronaria extract $(200 \mathrm{mg} / \mathrm{kg})$, isolated alkaloid rich fraction $(70 \mathrm{mg} / \mathrm{kg})$, and glaucine $(100 \mathrm{mg} / \mathrm{kg})$ showed a significant elevation in mechanical allodynia pain thresholds using Von-Frey-filaments. The results revealed that $A$. coronaria herb along with its most active alkaloid rich fraction and constituent (glaucine) possessed significant antihyperglycemic and antinociceptive potentials. These findings may lead to a future use of $A$. coronaria in the management of diabetic-neuropathy pain.
\end{abstract}

Abbreviations
AC: $\quad$ ethanolic extract of $A$. coronaria herb
BGL: $\quad$ blood glucose level
BW: body weight
CAT: $\quad$ catalase
DN: $\quad$ diabetic neuropathy

GLA: $\quad$ glaucine or compound 3

RP: $\quad$ reversed phase

SARF: isolated alkaloid rich fraction

T1DM: $\quad$ Type 1 Diabetes mellitus

TBARS: thiobarbituric acid reactive substances 


\section{Introduction}

Many genera of the family Ranunculaceae have large and colorful flowers and are being cultivated as ornamentals or for their pharmacological substances, which are commonly used in traditional Asian herbal medicine [1]. Anemone coronaria L. belongs to the family Ranunculaceae and is a winter perennial, flowering in the Mediterranean region from February until May [2]. A. coronaria was reported to contain anthocyanins (flowers), triterpene glycosides (tubers), and alkaloids (herb) [3-6]. A. coronaria has been used as antineuralgic and antirheumatic in the folk medicine of Lebanon [7]. Fresh A. coronaria flowers are reported to aid the healing of acute joint inflammation in traditional Turkish medicine [1]. In traditional Chinese medicine, $A$. coronaria is used to substitute Pulsatilla chinensis (Bunge) Regel (Ranunculaceae) roots in the management of neuralgic toothache and earache [8].

Currently, it is expensive for pharmaceutical companies to develop a single novel drug. As reported by Forbes, it can cost from 1 up to 5 billion US dollars [9]. Thus, phytochemicals might be more economical alternatives, important especially for low-income developing countries [10].

T1DM is a less-prevalent autoimmune disorder, comprising five percent of those diagnosed with diabetes, and mostly affecting kids and young adults. However, it is just as severe as type 2 diabetes [11].

T1DM is marked by demolished pancreatic beta cells resulting in insulin deficiency. Mounting evidence assumes that hyperglycemia management alone might be inadequate to prevent the progression of diabetic complications, thus, its early diagnosis and management are crucial for better therapeutic outcomes. However, complications are still the main cause of both mortality and morbidity in patients with T1DM [11].

DN is a common complication of T1DM and may cause serious pain. This pain might happen spontaneously, as hyperalgesia associated with mild painful stimuli, or as allodynia with non-noxious stimuli [12].

DN pain management substantiates an increasing therapeutic concern to clinicians, given that $39 \%$ of DN patients were not properly treated [13]. Moreover, the rest of the patients have been treat- ed with unspecific analgesics like tramadol and non-steroidal antiinflammatory drugs (NSAIDs), anticonvulsants or antidepressants [14]. Thus, it is important to find alternative therapies that are more specific and have fewer side-effects $[15,16]$.

A literature review indicated that there are no detailed studies on the effect of $A$. coronaria on diabetes-induced neuropathic pain. Consequently, the aim of the current work is to probe $A$. coronaria and its possible active principles for antinociceptive potentials against diabetic-neuropathy pain in a mouse model. This study also aimed to achieve a bio-guided fractionation, and to isolate the most active principles of $A$. coronaria.

\section{Results}

To isolate the active principles of AC, a bio-guided fractionation was conducted. Through RP-HPLC major peaks were identified as follows: I corrurine (12.6\%); II catalin (9.3\%); III thaliporphine (5.2\%); IV glaucine (19.9\%); V protopine (12.4\%). A mobile phase of triethylamine (0.1\%) and acetonitrile (60:40) was used at a flow rate of $1 \mathrm{~mL} / \mathrm{min}$ at $280 \mathrm{~nm}$, using UV detection ( $\triangleright$ Fig. 1 and Fig. S1, Supporting Information). The $A$. coronaria ethanolic extract was fractionated using RP-column chromatography. Each fraction was concentrated, dispersed in $0.9 \%$ cold sterile saline (vehicle), and examined for hypoglycemic and antinociceptive effects. The main active fraction was directly injected into the RP-HPLC apparatus to assess its patterns, and was found to be rich in alkaloids, hence it was named isolated alkaloid rich fraction (SARF). Four peaks were obtained from SARF, of which 3 peaks have been identified as catalin (21.1\%); thaliporphine (14.1\%); glaucine (compound 3, 63.4\%; - Fig. 1, 2), using a previously reported method [17]. The peak concentrations were measured utilizing the area under-peaks, and the peak areas were found to be directly proportional to the sample amount utilizing standard calibration curves and steep-area method. A comparison of the ${ }^{1} \mathrm{H}$ NMR and ${ }^{13} \mathrm{C}$ NMR analysis to standards ascertained that SARF contained catalin, thaliporphine, and glaucine (3; - Fig. 1 and Table. S1, Supporting Information).

The experimental protocol of the in vivo tests is summarized in - Table 1. The levels of HbA1c (\%), measured at the end of eight
1<smiles>O=C(O)c1cc(O)c2c3nc4ccccc4oc-3cc(=O)c2n1</smiles><smiles>COc1cc2c(cc1OC)-c1c(O)c(OC)cc3c1C(C2)N(C)CC3</smiles>

3<smiles>COc1cc2c(cc1OC)-c1c(OC)c(OC)cc3c1[C@@H](C2)N(C)CC3</smiles>

Fig. 1 Isolated compounds from A. coronaria active fraction (SARF). a catalin; b thaliporphine; c glaucine. 


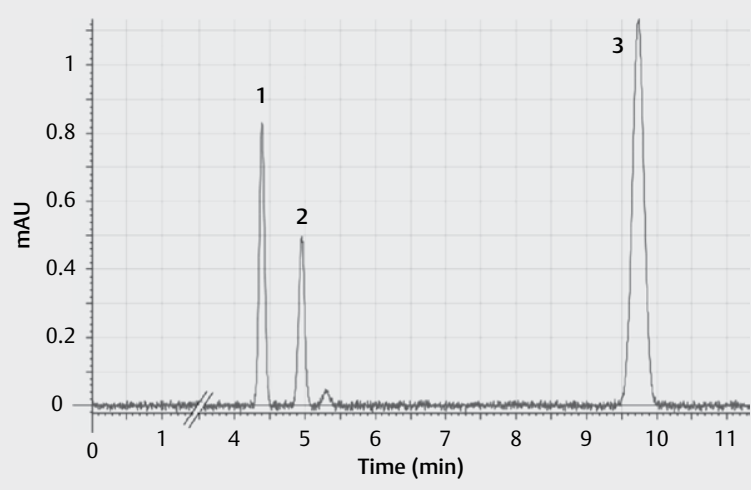

- Fig. 2 HPLC chromatogram of SARF. Peaks are as follows: 1 catalin (21.1\%); 2 thaliporphine (14.1\%); 3 glaucine (63.4\%) using mobile phase of triethylamine $(0.1 \%)$ and acetonitrile $(60: 40)$ at a flow rate of $1 \mathrm{~mL} / \mathrm{min}$ at $280 \mathrm{~nm}$ using UV detector.

- Table 1 Protocol of the experimental design.

\begin{tabular}{|c|c|c|c|}
\hline Groups & $\mathbf{n}$ & $\begin{array}{l}\text { Tested } \\
\text { Substance(s) }\end{array}$ & Description \\
\hline \multicolumn{4}{|c|}{$\begin{array}{l}\text { A Acute }(0,0.5,2 \text { and } 6 \mathrm{~h}) \text { and subchronic }(1,3,5 \text {, and } 8 \text { days) effects } \\
\text { of Anemone coronaria ethanolic extract (A. coronaria), its alkaloid rich } \\
\text { fraction (SARF) and glaucine (GLA) on blood glucose, body weights, } \\
\text { and CAT serum levels: }\end{array}$} \\
\hline 1 & 7 & Control & $\begin{array}{l}\text { Normal mice: Vehicle [sterile } \\
\text { cold saline }(0.9 \%) \text { ] }\end{array}$ \\
\hline II & 7 & Diabetic Control & Diabetic mice: Vehicle \\
\hline III & 7 & GB & Diabetic mice: GB 5 mg/kg \\
\hline IV & 7 & A. coronaria & $\begin{array}{l}\text { Diabetic mice: A. coronaria } \\
50 \mathrm{mg} / \mathrm{kg}\end{array}$ \\
\hline $\mathrm{V}$ & 7 & A. coronaria & $\begin{array}{l}\text { Diabetic mice: A. coronaria } \\
100 \mathrm{mg} / \mathrm{kg}\end{array}$ \\
\hline $\mathrm{VI}$ & 7 & A. coronaria & $\begin{array}{l}\text { Diabetic mice: A. coronaria } \\
200 \mathrm{mg} / \mathrm{kg}\end{array}$ \\
\hline VII & 7 & SARF & Diabetic mice: SARF $70 \mathrm{mg} / \mathrm{kg}$ \\
\hline VIII & 7 & GLA & Diabetic mice: GLA 25 mg/kg \\
\hline IX & 7 & GLA & Diabetic mice: GLA 50 mg/kg \\
\hline$x$ & 7 & GLA & Diabetic mice: GLA $100 \mathrm{mg} / \mathrm{kg}$ \\
\hline \multicolumn{4}{|c|}{$\begin{array}{l}\text { B Subchronic }(0,2,4,6 \text { and } 8 \text { weeks) effect of } A \text {. coronaria, SARF, and } \\
\text { GLA on hot plate and tail withdrawal latencies, and von Frey paw } \\
\text { withdrawal thresholds: }\end{array}$} \\
\hline$X I$ & 7 & NORM & $\begin{array}{l}\text { Normal mice: Vehicle [sterile } \\
\text { cold saline }(0.9 \%) \text { ] }\end{array}$ \\
\hline XII & 7 & VEH & Diabetic mice: Vehicle \\
\hline XIII & 7 & A. coronaria & $\begin{array}{l}\text { Diabetic mice: A. coronaria } \\
50 \mathrm{mg} / \mathrm{kg}\end{array}$ \\
\hline XIV & 7 & A. coronaria & $\begin{array}{l}\text { Diabetic mice: A. coronaria } \\
100 \mathrm{mg} / \mathrm{kg}\end{array}$ \\
\hline $\mathrm{XV}$ & 7 & A. coronaria & $\begin{array}{l}\text { Diabetic mice: A. coronaria } \\
200 \mathrm{mg} / \mathrm{kg}\end{array}$ \\
\hline $\mathrm{XVI}$ & 7 & SARF & Diabetic mice: SARF $70 \mathrm{mg} / \mathrm{kg}$ \\
\hline $\mathrm{XVII}$ & 7 & GLA & Diabetic mice: GLA 25 mg/kg \\
\hline $\mathrm{XVIII}$ & 7 & GLA & Diabetic mice: GLA $50 \mathrm{mg} / \mathrm{kg}$ \\
\hline $\mathrm{XIX}$ & 7 & GLA & Diabetic mice: GLA $100 \mathrm{mg} / \mathrm{kg}$ \\
\hline
\end{tabular}

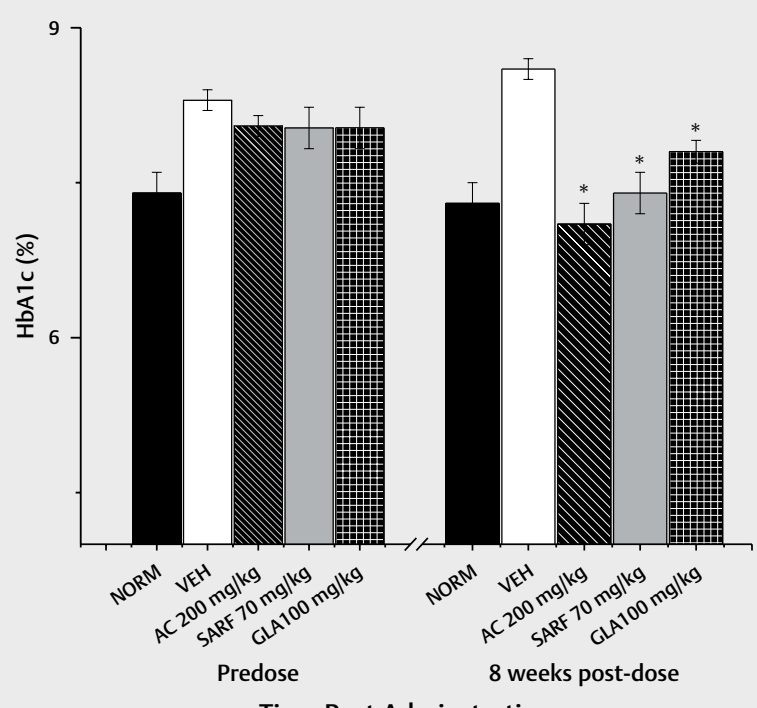

- Fig. 3 Effects of $A$. coronaria extract (AC), its alkaloid rich fraction (SARF) and glaucine (GLA) on $\mathrm{HbA} 1 \mathrm{c}$ at pre-dose and 8 weeks postdose. Values represent the mean \pm SEM $(n=7)$. (NORM) normal non-diabetic untreated mice. ${ }^{*} \mathrm{p}<0.05$ vs. diabetic vehicle control (VEH).

weeks for different experimental groups, are shown in > Fig. 3. A significant elevation of the HbA1c level $(p \leq 0.05)$ was detected in the vehicle control mice (VEH; $8.30 \pm 0.10)$ when compared with normal control mice (NORM; $7.40 \pm 0.14)$. After eight weeks of treatment with AC $(200 \mathrm{mg} / \mathrm{kg} ; 7.10 \pm 0.09)$, SARF $(70 \mathrm{mg} / \mathrm{kg}$; $7.41 \pm 0.08)$, and compound $3(100 \mathrm{mg} / \mathrm{kg} ; 7.80 \pm 0.07)$ the $\mathrm{HbA} 1 \mathrm{c}$ levels in alloxan-induced diabetic mice ameliorated near to the normal-ranges, significantly $(p \leq 0.05)$ relative to $V E H$ mice $(8.30 \pm 0.10)$ and near to the normal ranges compared with NORM mice, indicating that AC, SARF, and compound $\mathbf{3}$ worked as potential hypoglycemic agents.

To assess the therapeutic effects of the tested compounds on diabetes, the acute anti-diabetic activities of AC, SARF, and compound 3 were examined for $6 \mathrm{~h}$ ( $\triangleright$ Table 2 ). Glibenclamide $(5 \mathrm{mg} /$ $\mathrm{kg}$ ) was used as a positive control to validate the experimental protocol and procedure, and showed a significant acute reduction in BGL [18]. Acute administration of AC to alloxan-induced diabetic mice at various doses $(50,100$, and $200 \mathrm{mg} / \mathrm{kg})$ induced a sustained decrease of $40.4,43.7$, and $53.1 \%$, respectively, in BGL over a 6 -h period relative to the diabetic control-group. While SARF displayed a $48.4 \%$ decrease in BGL relative to the diabetic control group after $6 \mathrm{~h}$, compound $3(25,50$, and $100 \mathrm{mg} / \mathrm{kg})$ however, showed 36.8 , 38.4 , and $45.6 \%$, respectively, reduction in BGL after $6 \mathrm{~h}$ Consequently, the highest dose of AC showed a higher efficacy than SARF and glaucine (3), acutely.

AC is commonly commercialized in the folk medicine of Lebanon for the management of several disorders, including diabetes. This use has encouraged the performance of this study to prove its preclinical efficacy as a potential hypoglycemic agent using wellestablished mice models [19]. To verify this, subchronic adminis- 
> Table 2 Acute effect of A. coronaria hexane extract, its alkaloid rich fraction (SARF), and glaucine (GLA) on blood glucose.

\begin{tabular}{|l|c|c|c|c|c|}
\hline \multirow{2}{*}{ Group } & \multirow{2}{*}{ Dose (mg/kg) } & \multicolumn{4}{|c|}{ Mean blood glucose concentration \pm S.E.M. (mg/dL) } \\
\cline { 2 - 6 } & & $\mathbf{0 h}$ & $\mathbf{0 . 5} \mathbf{h}$ & $\mathbf{2 h}$ & $\mathbf{6 h}$ \\
\hline Control & - & $101.80 \pm 1.80$ & $106.50 \pm 3.50$ & $104.13 \pm 3.10$ & $107.25 \pm 3.90$ \\
\hline Diabetic control & - & $204.79 \pm 5.60$ & $214.63 \pm 4.50$ & $216.91 \pm 9.70$ & $212.25 \pm 7.30$ \\
\hline GB & 5 & $220.70 \pm 2.70$ & $223.64 \pm 1.80$ & $159.74 \pm 2.10$ & $130.60 \pm 2.40^{* *}$ \\
\hline A. coronaria & 50 & $205.51 \pm 2.40$ & $172.45 \pm 2.30$ & $172.87 \pm 3.50$ & $126.59 \pm 2.40^{*}$ \\
\hline A. coronaria & 100 & $211.33 \pm 2.70$ & $166.78 \pm 2.90$ & $166.87 \pm 2.90$ & $119.59 \pm 2.30^{*}$ \\
\hline A. coronaria & 200 & $202.20 \pm 2.10$ & $114.67 \pm 1.90$ & $114.87 \pm 2.30$ & $99.59 \pm 2.70^{*}$ \\
\hline SARF & 70 & $211.90 \pm 2.80$ & $124.83 \pm 1.90$ & $126.81 \pm 1.80$ & $109.58 \pm 1.30^{*}$ \\
\hline GLA & 25 & $204.54 \pm 2.10$ & $191.45 \pm 2.90$ & $129.67 \pm 2.40$ & $134.12 \pm 1.50^{*}$ \\
\hline GLA & 50 & $212.90 \pm 2.70$ & $180.36 \pm 2.10$ & $147.33 \pm 2.40$ & $130.76 \pm 1.70^{*}$ \\
\hline GLA & 100 & $206.34 \pm 1.20$ & $156.26 \pm 2.00$ & $136.55 \pm 2.10$ & $115.44 \pm 2.20^{*}$ \\
\hline S.E.M.: mean standard error & & & & \\
\hline$*$ P<0.05 significant from the control animals & \\
\hline
\end{tabular}

- Table 3 Subchronic effect of A. coronaria, SARF, and GLA on blood glucose.

\begin{tabular}{|c|c|c|c|c|c|}
\hline \multirow{2}{*}{ Group } & \multirow{2}{*}{ Dose $(\mathrm{mg} / \mathrm{kg})$} & \multicolumn{4}{|c|}{ Mean blood glucose concentration \pm S.E.M. (mg/dL) } \\
\hline & & 1st day & 3rd day & 5th day & 8th day \\
\hline Control & - & $105.10 \pm 2.50$ & $107.10 \pm 3.60$ & $106.10 \pm 2.20$ & $110.40 \pm 3.70$ \\
\hline Diabetic controla & - & $202.79 \pm 5.60 * * *$ & $211.93 \pm 4.50^{* * *}$ & $215.21 \pm 9.70^{* * *}$ & $210.50 \pm 7.30 * * *$ \\
\hline $\mathrm{GB}^{\mathrm{b}}$ & 5 & $184.20 \pm 3.70$ & $177.03 \pm 2.90$ & $159.04 \pm 2.40^{* *}$ & $169.80 \pm 3.10$ \\
\hline A. coronaria & 50 & $127.59 \pm 2.40$ & $150.67 \pm 2.30$ & $144.33 \pm 2.30$ & $139.63 \pm 2.40^{*}$ \\
\hline A. coronaria ${ }^{\mathrm{a}}$ & 100 & $120.41 \pm 2.30$ & $122.69 \pm 2.10$ & $120.45 \pm 1.90$ & $115.33 \pm 2.10^{*}$ \\
\hline A. coronaria & 200 & $100.59 \pm 2.70$ & $105.88 \pm 2.70$ & $105.73 \pm 2.40$ & $97.34 \pm 2.90^{*}$ \\
\hline SARFa & 70 & $110.58 \pm 1.30$ & $109.89 \pm 3.10$ & $109.22 \pm 2.50$ & $108.13 \pm 1.30^{*}$ \\
\hline $\mathrm{GLA}^{\mathrm{a}}$ & 25 & $135.12 \pm 1.50$ & $139.76 \pm 2.10$ & $124.76 \pm 2.10$ & $123.76 \pm 2.50^{*}$ \\
\hline $\mathrm{GLA}^{\mathrm{a}}$ & 50 & $131.66 \pm 1.70$ & $129.48 \pm 2.40$ & $125.76 \pm 2.00$ & $120.55 \pm 2.20^{*}$ \\
\hline $\mathrm{GLA}^{\mathrm{a}}$ & 100 & $120.44 \pm 2.20$ & $120.26 \pm 2.20$ & $119.26 \pm 2.10$ & $114.98 \pm 2.10^{*}$ \\
\hline \multicolumn{6}{|c|}{ S.E.M.: mean standard error } \\
\hline \multicolumn{6}{|c|}{${ }^{*} \mathrm{p}<0.05$ significant from the control animals } \\
\hline \multicolumn{6}{|c|}{${ }^{* *} \mathrm{p}<0.01$ significant from the control animals } \\
\hline \multicolumn{6}{|c|}{${ }^{* * *} \mathrm{p}<0.001$ significant from the control animals } \\
\hline \multicolumn{6}{|c|}{ a Compared to vehicle control } \\
\hline${ }^{b}$ Compared to dia & trol & & & & \\
\hline
\end{tabular}

tration of AC to alloxan-induced diabetic mice at various doses ( 50 , 100 , and $200 \mathrm{mg} / \mathrm{kg}$ ) induced a sustained decrease of 33.7, 45.2, and $53.8 \%$, respectively, in BGL for eight days as compared with the diabetic control group ( $\triangleright$ Table 3), while SARF had a $48.6 \%$ decrease in BGL relative to the diabetic control group 8 days post-administration. On the other hand, glaucine $(3 ; 25,50$, and $100 \mathrm{mg} /$ $\mathrm{kg}$ ) showed 41.2, 42.8, and $45.4 \%$, respectively, reduction in $\mathrm{BGL}$ after $6 \mathrm{~h}$ post-administration relative to the diabetic control-group. Accordingly, the highest dose of AC showed a higher efficacy than SARF and glaucine (3), subchronically.

The elevation in BW of the experimental-animals is an indicator for the amelioration of hyperglycemia $[20,21]$ ( Table 4). Therefore, the effects of AC, SARF, and glaucine (3) on BW levels of the mice were monitored for eight days during the experimental period ( $\triangleright$ Fig. 4). The BW levels of the control diabetic animals gradually decreased throughout the experimental period, indicating an aggravation of diabetes. On the other hand, the BW levels of the AC $(50,100$ and, $200 \mathrm{mg} / \mathrm{kg})$ treated group increased by $2.3,6.3$, and $14.7 \%$, respectively, 8 days post-administration as compared to the diabetic control group. Eight days after SARF $(70 \mathrm{mg} / \mathrm{kg})$ administration, BW levels increased by $15.1 \%$ relative to the diabetic control group. Compound $3(25,50$, and $100 \mathrm{mg} / \mathrm{kg})$ treated groups showed 9.0, 14.6, and $17.3 \%$, respectively, increase in BW levels when compared to the diabetic control group 8 days postadministration. Accordingly, the diabetic mice treated with AC, SARF, and compound 3 had a significant elevation on BW gain rela- 
- Table 4 Subchronic effect of A. coronaria, SARF, and GLA on body weights in alloxan-induced diabetic mice.

\begin{tabular}{|c|c|c|c|c|c|}
\hline \multirow{2}{*}{ Group } & \multirow{2}{*}{ Dose (mg/kg) } & \multicolumn{4}{|c|}{ Mean body weight \pm S.E.M. $(\mathrm{gm})$ ( $\%$ increase from the vehicle control) } \\
\hline & & 1st day & 3rd day & 5th day & 8th day \\
\hline Control & - & $26.40 \pm 0.50$ & $26.50 \pm 0.60$ & $26.66 \pm 0.97$ & $26.72 \pm 0.70$ \\
\hline Diabetic controla & - & $27.18 \pm 0.70$ & $27.60 \pm 0.20(4.2 \%)$ & $27.65 \pm 0.80(3.7 \%)$ & $\begin{array}{c}27.00 \pm 0.50 \\
(-0.4 \%)\end{array}$ \\
\hline $\mathrm{GB}^{\mathrm{a}}$ & 5 & $25.40 \pm 0.70$ & $30.67 \pm 1.70(8.1 \%)$ & $31.04 \pm 0.40(8.8 \%)$ & $\begin{array}{c}32.87 \pm 1.10^{*} \\
(13.7 \%)\end{array}$ \\
\hline A. coronaria & 50 & $28.00 \pm 1.80$ & $\begin{array}{c}30.10 \pm 1.30 \\
(0.4 \%)\end{array}$ & $\begin{array}{c}30.50 \pm 1.50 \\
(1.8 \%)\end{array}$ & $\begin{array}{c}30.63 \pm 1.40 * \\
(2.25 \%)\end{array}$ \\
\hline A. coronaria & 100 & $29.46 \pm 2.70$ & $\begin{array}{c}30.30 \pm 1.10 \\
(3.0 \%)\end{array}$ & $\begin{array}{c}30.90 \pm 1.30 \\
(5.2 \%)\end{array}$ & $\begin{array}{c}31.20 \pm 1.10^{*} \\
(6.3 \%)\end{array}$ \\
\hline A. coronaria & 200 & $28.46 \pm 2.10$ & $\begin{array}{c}30.88 \pm 1.70 \\
(9.1 \%)\end{array}$ & $\begin{array}{c}31.77 \pm 1.40 \\
(12.5 \%)\end{array}$ & $\begin{array}{c}32.34 \pm 1.90^{*} \\
(14.7 \%)\end{array}$ \\
\hline SARFa & 70 & $29.55 \pm 0.40$ & $\begin{array}{c}30.85 \pm 0.80 \\
(4.7 \%)\end{array}$ & $\begin{array}{c}32.61 \pm 1.20 \\
(11.1 \%)\end{array}$ & $\begin{array}{c}33.71 \pm 1.40^{*} \\
(15.1 \%)\end{array}$ \\
\hline $\mathrm{GLA}^{\mathrm{a}}$ & 25 & $29.56 \pm 0.80$ & $\begin{array}{c}28.66 \pm 0.30 \\
(4.0 \%)\end{array}$ & $\begin{array}{c}30.99 \pm 0.90 \\
(5.2 \%)\end{array}$ & $\begin{array}{c}32.05 \pm 0.40^{*} \\
(9.0 \%)\end{array}$ \\
\hline $\mathrm{GLA}^{\mathrm{a}}$ & 50 & $29.10 \pm 0.40$ & $\begin{array}{c}28.50 \pm 0.40 \\
(5.2 \%)\end{array}$ & $\begin{array}{c}31.50 \pm 0.50 \\
(8.9 \%)\end{array}$ & $\begin{array}{c}33.05 \pm 0.80 * \\
(14.6 \%)\end{array}$ \\
\hline $\mathrm{GLA}^{\mathrm{a}}$ & 100 & $28.50 \pm 0.20$ & $\begin{array}{c}27.90 \pm 0.70 \\
(5.3 \%)\end{array}$ & $\begin{array}{c}32.05 \pm 0.30 \\
(13.4 \%)\end{array}$ & $\begin{array}{c}33.09 \pm 0.20 * \\
(17.3 \%)\end{array}$ \\
\hline \multicolumn{6}{|c|}{ S.E.M.: mean standard error } \\
\hline \multicolumn{6}{|c|}{${ }^{*} \mathrm{p}<0.05$ significant from the control animals } \\
\hline \multicolumn{6}{|c|}{${ }^{\text {a Compared to vehicle control }}$} \\
\hline
\end{tabular}
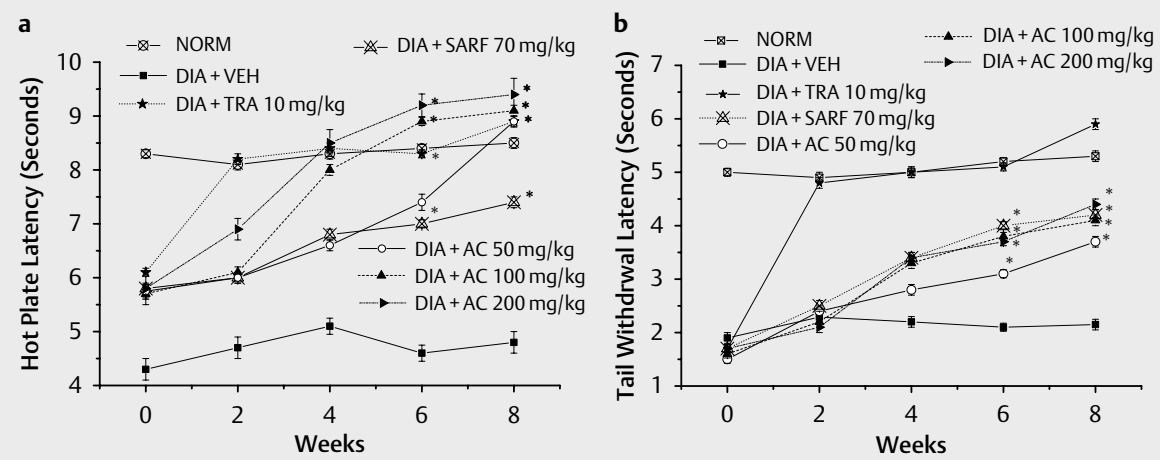

- Fig. 4 Effect of A. coronaria extract (AC) and its alkaloid rich fraction (SARF), using tramadol (TRA) $10 \mathrm{mg} / \mathrm{kg}$ as a positive standard, a on the hot plate latency and $\mathbf{b}$ on the tail flick latency, in alloxan treated mice (DIA) and untreated (NORM). "* " means p $<0.05$ compared with control. Data $(n=7)$ are expressed in mean \pm S.E.M.

tive to diabetic control-groups, indicating the amelioration of hyperglycemia.

CAT enzyme activity, analyzed in alloxan-provoked diabetic mice, was significantly $(p<0.001)$ declined relative to normal controls ( $\triangleright$ Table 5). After eight days of AC administration using 50, 100 , and $200 \mathrm{mg} / \mathrm{kg}$ doses, the antioxidant CAT levels were significantly $(p<0.05)$ increased by $40.2,40.7$, and $59.0 \%$, respectively, as compared to the diabetic control group. The CAT levels were also increased by $54.0 \% 8$ days post-administration of the isolated SARF $(70 \mathrm{mg} / \mathrm{kg})$ as related to the diabetic control group. Moreover, compound 3 at doses 25,50 and $100 \mathrm{mg} / \mathrm{kg}$ improved CAT levels by $10.0,15.5$, and $29.8 \%$, respectively, after 8 days of administration as compared to the diabetic control group. The lipid peroxidation, measured as TBARS levels, analyzed in alloxan-provoked diabetic mice, was significantly $(p<0.05)$ increased relative to normal control ( $\triangleright$ Table 6). After 8 weeks of AC $(200 \mathrm{mg} / \mathrm{kg})$, SARF $(70 \mathrm{mg} / \mathrm{kg})$, and compound $3(100 \mathrm{mg} / \mathrm{kg})$ administration, the TBARS levels were significantly $(p<0.05)$ decreased by $72.1,63.8$, and $46.6 \%$, respectively, as compared to the diabetic vehicle group. The glutathione levels, analyzed in alloxan-provoked diabetic mice, were significantly $(p<0.05)$ decreased relative to normal controls ( $\triangleright$ Table 6). After 8 weeks of AC (200 mg/kg), SARF (70 mg/kg), and compound $3(100 \mathrm{mg} / \mathrm{kg})$ administration, the glutathione levels were significantly $(p<0.05)$ elevated by $66.6,47.7$ and $26.0 \%$, re- 
- Table 5 In vivo assessment of the antioxidant activity of A. coronaria, SARF, and GLA using CAT levels in serum of alloxan-induced diabetic mice.

\begin{tabular}{|c|c|c|c|c|c|}
\hline \multirow{2}{*}{ Group } & \multirow{2}{*}{ Dose $(\mathrm{mg} / \mathrm{kg})$} & \multicolumn{4}{|c|}{ Catalase level \pm S.E.M. (kU/I) } \\
\hline & & 1st day & 3rd day & 5th day & 8th day \\
\hline Control & - & $37.50 \pm 1.40$ & $38.10 \pm 1.50$ & $39.26 \pm 1.20$ & $38.12 \pm 1.60$ \\
\hline Diabetic controla $^{\mathrm{a}}$ & - & $19.71 \pm 1.60 * * *$ & $19.63 \pm 1.30^{* * *}$ & $19.51 \pm 1.90 * * *$ & $18.75 \pm 1.40^{* * *}$ \\
\hline $\mathrm{GB}^{\mathrm{b}}$ & 5 & $19.10 \pm 1.70$ & $21.50 \pm 1.70$ & $28.04 \pm 1.40$ & $28.87 \pm 1.00 * *$ \\
\hline A. coronaria ${ }^{\mathrm{a}}$ & 50 & $19.61 \pm 1.20$ & $20.90 \pm 1.60$ & $24.16 \pm 2.40$ & $26.28 \pm 3.10^{*}$ \\
\hline A. coronaria & 100 & $20.13 \pm 1.70$ & $22.92 \pm 1.20$ & $23.10 \pm 2.70$ & $26.38 \pm 2.90^{*}$ \\
\hline A. coronaria ${ }^{\mathrm{a}}$ & 200 & $18.94 \pm 2.10$ & $22.16 \pm 1.70$ & $27.10 \pm 2.50$ & $29.82 \pm 1.60^{*}$ \\
\hline SARF & 70 & $20.44 \pm 1.60$ & $26.73 \pm 1.40$ & $28.64 \pm 1.80$ & $28.87 \pm 1.30^{* *}$ \\
\hline $\mathrm{GLA}^{\mathrm{a}}$ & 25 & $19.12 \pm 1.90$ & $19.47 \pm 2.70$ & $19.45 \pm 2.65$ & $20.55 \pm 2.60^{* *}$ \\
\hline $\mathrm{GLA}^{\mathrm{a}}$ & 50 & $20.89 \pm 2.10$ & $20.44 \pm 2.50$ & $20.80 \pm 1.90$ & $21.65 \pm 2.40^{* *}$ \\
\hline $\mathrm{GLA}^{\mathrm{a}}$ & 100 & $19.22 \pm 2.20$ & $21.44 \pm 2.80$ & $23.10 \pm 2.10$ & $24.34 \pm 1.90^{* *}$ \\
\hline \multicolumn{6}{|c|}{ S.E.M.: mean standard error } \\
\hline \multicolumn{6}{|c|}{${ }^{*} p<0.05$ significant from the control animals } \\
\hline \multicolumn{6}{|c|}{${ }^{* *} p<0.01$ significant from the control animals } \\
\hline \multicolumn{6}{|c|}{${ }^{* * *} p<0.001$ significant from the control animals } \\
\hline \multicolumn{6}{|c|}{ a Compared to vehicle control } \\
\hline b Compared to dia & ontrol & & & & \\
\hline
\end{tabular}

- Table 6 Effect of A. coronaria, SARF and GLA on alloxan-induced alterations in TBARS and reduced GSH (mean \pm S.E.M.).

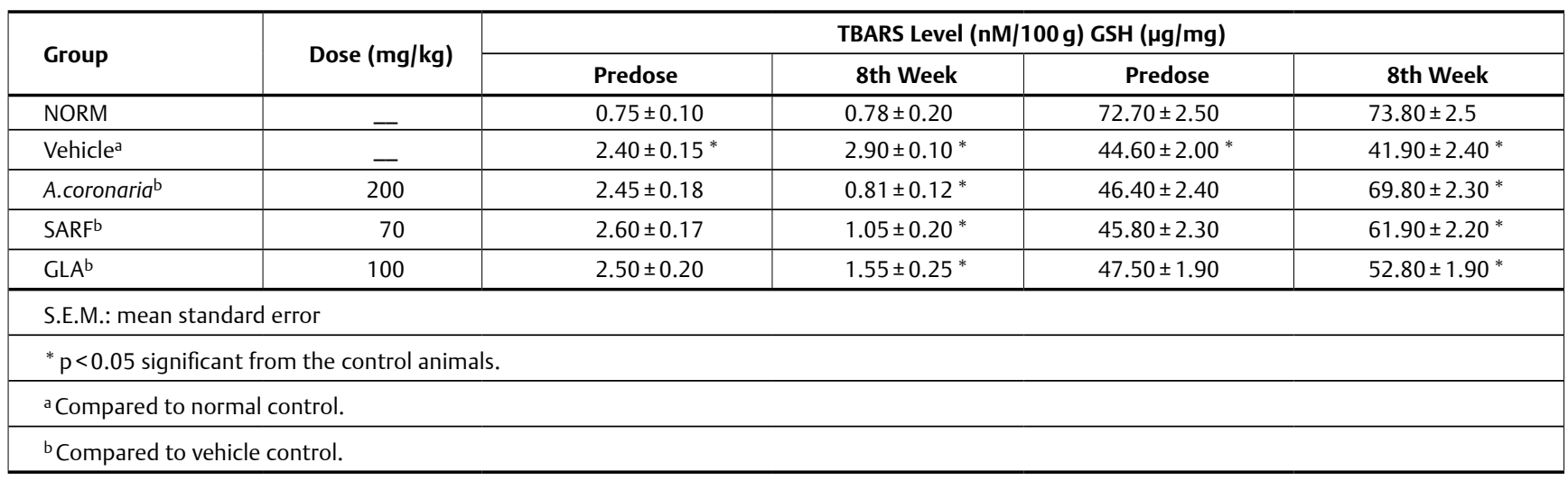
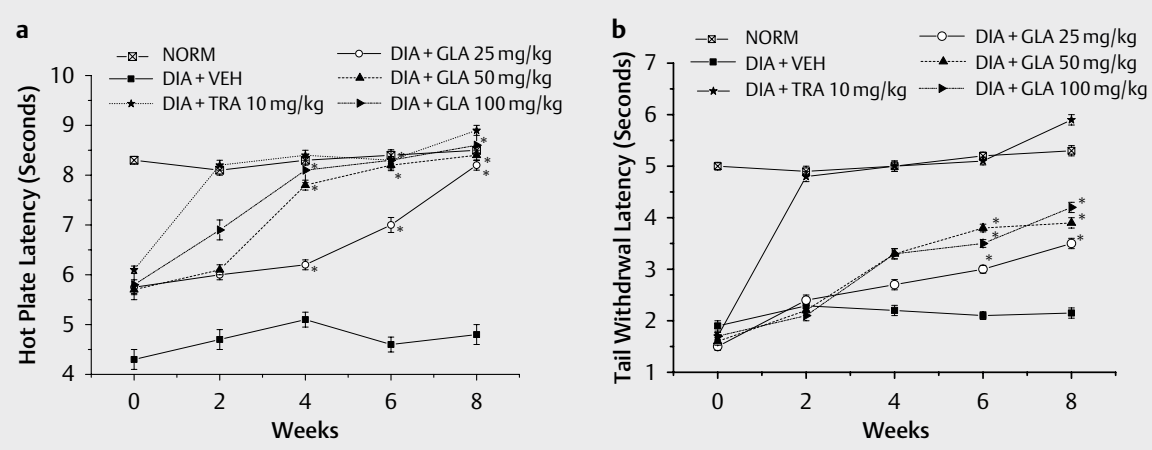

- Fig.5 Effect of glaucine (GLA) using tramadol (TRA) $10 \mathrm{mg} / \mathrm{kg}$ as a positive standard, $\mathbf{a}$ on the hot plate latency and $\mathbf{b}$ on the tail flick latency, in alloxan treated mice (DIA) and untreated (NORM). " * " means $p<0.05$ compared with control. Data $(n=7)$ are expressed in mean \pm S.E.M.

spectively, as compared to the diabetic vehicle group. As shown, the herbal extract showed a more powerful antioxidant effect than the isolated active fraction and compound $\mathbf{3}$, which apparently was due to the additive properties of the active principles along with other compounds in the plant extract. 
- Table 7 The effect of A. coronaria, SARF, GLA, and tramadol (TRA) $10 \mathrm{mg} / \mathrm{kg}$ on Von Frey filaments tactile allodynia thresholds in neuropathic model in alloxan-induced diabetic mice.

\begin{tabular}{|c|c|c|c|c|c|c|}
\hline \multirow{2}{*}{ Group } & \multirow{2}{*}{ Dose $(\mathrm{mg} / \mathrm{kg})$} & \multicolumn{5}{|c|}{ Tactile allodynia thresholds \pm S.E.M. (gm) } \\
\hline & & Predose & 2nd Week & 4th Week & 6th Week & 8th Week \\
\hline NORM & $\ldots$ & $8.70 \pm 0.20$ & $8.80 \pm 0.22$ & $9.20 \pm 0.30$ & $8.80 \pm 0.24$ & $9.10 \pm 0.20$ \\
\hline Vehicle $^{a}$ & - & $2.50 \pm 0.21^{* * *}$ & $2.80 \pm 0.30^{* * *}$ & $2.45 \pm 0.27^{* * *}$ & $2.50 \pm 0.20 * * *$ & $2.55 \pm 0.19 * * *$ \\
\hline TRA $^{\mathrm{b}}$ & 10 & $3.00 \pm 0.10$ & $24.00 \pm 1.00$ & $24.50 \pm 1.10$ & $24.60 \pm 1.30$ & $25.10 \pm 1.00^{* *}$ \\
\hline A.coronariab & 200 & $3.20 \pm 2.20$ & $7.50 \pm 0.12$ & $8.70 \pm 0.20$ & $17.00 \pm 0.40$ & $20.50 \pm 0.20^{*}$ \\
\hline SARF $^{b}$ & 70 & $3.00 \pm 0.10$ & $8.00 \pm 0.20$ & $8.60 \pm 0.40$ & $16.80 \pm 0.30$ & $18.00 \pm 0.50^{*}$ \\
\hline $\mathrm{GLA}^{\mathrm{b}}$ & 100 & $3.10 \pm 0.20$ & $7.50 \pm 0.30$ & $7.80 \pm 0.50$ & $13.00 \pm 1.20$ & $16.00 \pm 1.20^{*}$ \\
\hline \multicolumn{7}{|c|}{ S.E.M.: mean standard error } \\
\hline \multicolumn{7}{|c|}{${ }^{*} p<0.05$ significant from the control animals } \\
\hline \multicolumn{7}{|c|}{${ }^{* *} \mathrm{p}<0.01$ significant from the control animals } \\
\hline \multicolumn{7}{|c|}{${ }^{* * *} \mathrm{p}<0.001$ significant from the control animals } \\
\hline \multicolumn{7}{|c|}{ a Compared to normal control } \\
\hline \multicolumn{7}{|c|}{${ }^{\mathrm{b}}$ Compared to vehicle control } \\
\hline
\end{tabular}

After 8 weeks of development of diabetes, diabetic mice developed thermal hyperalgesia marked by a significant latency decrease to noxious heat $(8.49 \pm 0.19 \mathrm{~S}$ at baseline to $4.80 \pm 0.20 \mathrm{~S}$ in hot plate latency, and $5.29 \pm 0.02 \mathrm{~S}$ at baseline to $2.16 \pm 0.02 \mathrm{~s}$ in tail flick latency; - Fig. 4). To validate the procedure, tramadol (TRA; $10 \mathrm{mg} / \mathrm{kg}$ ) was utilized as a positive control and decreased alloxaninduced thermal hyperalgesia, elevating the hot plate withdrawal latency by $85.2 \%$, and that of tail-withdrawal latency by $173.1 \%, 8$ weeks post-administration ( $\triangleright$ Fig. 5). Treatment of mice with various doses of $A C(50,100$, and $200 \mathrm{mg} / \mathrm{kg}$, orally) increased the hot plate latency by $85.0,87.5$ and $95.6 \%$, respectively, and that of tailwithdrawal latency by $72.2,89.9,103.7 \%$, respectively, 8 weeks post-administration as compared to the diabetic control group ( $>$ Fig. 4). In addition, SARF (70 mg/kg) also decreased alloxan-induced thermal hyperalgesia, elevating the hot plate withdrawal latency by $54.0 \%$ and of that of tail-withdrawal latency by $94.4 \%, 8$ weeks post-administration ( $\$$ Fig. 4). Moreover, the oral administration of various doses of compound $3(25,50,100 \mathrm{mg} / \mathrm{kg})$ resulted in an increase of the hot-plate latency by $70.8,74.8$ and $79.2 \%$, respectively, and that of tail-withdrawal latency by $62.0,80.5$, $94.4 \%$, respectively, 8 weeks post-administration as compared to the diabetic control group ( $\triangleright$ Fig. 5).

Mechanical allodynia was provoked in alloxan-induced diabetic mice after 8 weeks of diabetes induction, which was marked by a significant decrease in paw-withdrawal threshold upon application of Von-Frey filaments $(9.10 \pm 0.20 \mathrm{~g}$ at baseline to $2.55 \pm 0.19 \mathrm{~g}$ after 8 weeks for vehicle-treated diabetic group; - Table 7). The management of neuropathic animals with AC $(200 \mathrm{mg} / \mathrm{kg})$, SARF $(70 \mathrm{mg} / \mathrm{kg})$ and compound $3(100 \mathrm{mg} / \mathrm{kg})$ significantly reduced the tactile allodynia, 8 weeks post-administration, by 7.0, 6.0, and 5.3 folds, respectively ( $\triangleright$ Table 7). To validate the procedure, treatment of neuropathic mice with TRA $(10 \mathrm{mg} / \mathrm{kg}$, utilized as positive-control) also lowered the mechanical allodynia by 8.8 folds 8 weeks after the treatment ( $\triangleright$ Table 7 ).

The mortality rate in the untreated diabetic group was significantly increased (36.4\%) in comparison to the normal non-diabetic group. In contrast, animals treated with AC showed a lower rate of mortality in correlation to the vehicle-control group (10.6\%). For SARF- and compound 3-treated groups, animals showed a lower mortality rate in comparison to the vehicle-control group (11.4 and 13.7\%).

\section{Discussion}

In folk medicine, $A$. coronaria is an essential medicinal plant used by the Lebanese population as antineuralgic and antirheumatic [7]. Nevertheless, the exact neuroprotective activity of AC and its most active principles were not studied thoroughly. Thus, this study was designed to assess $A C$ and its possible active principles for their phytochemical and pharmacological properties in experimental models of hyperglycemia, thermal and mechanical nociception, as well as to investigate mortality rates before and after administration. However, it is the first report demonstrating a potential of $A$. coronaria for improvement in alloxan-induced neuropathy in mice. The bio-guided fractionation and isolation of the active principles in AC showed that its most active fraction is rich in alkaloids, hence it was named isolated alkaloid rich fraction (SARF). SARF was found to be rich in the alkaloid glaucine (compound 3 ). Therefore, SARF and compound $\mathbf{3}$ were thoroughly studied to monitor their hypoglycemic and antinociceptive potentials.

In this study, chemical induction of T1DM was performed utilizing alloxan to provoke and maintain hyperglycemia in mice during the experimental period. Alloxan-induced persistent elevation in $B G L$ resulted from an inadequate production and the release of insulin attributed to pancreatic $\beta$-cells destruction by oxidative stress and superoxide radical formation provoked by alloxan [22].

Data from the present study showed that the administration of AC, SARF and compound 3 for $6 \mathrm{~h}$ (acute) and 8 days (subchronic) ameliorated the elevated BGL of alloxan-induced diabetic mice to near the BGL baseline range $(107.25 \pm 7.30 \mathrm{mg} / \mathrm{dL})$ in the non-diabetic control group. Thus, this study has established the antidiabetic activity and a possible future usage of $A C$ for the amelioration of diabetes mellitus. Administration of various doses of AC and compound 3 caused dose-dependent BGL lowering effects. However, the highest dose of AC showed more powerful hypoglycemic 
activity than that of SARF and compound 3 . Moreover, the highest doses of AC, SARF and compound $\mathbf{3}$ showed significant stabilizations of BGL for longer times (8 weeks) as indicated by HbA1c-experiments. Furthermore, HbA1c levels showed more stabilization of BGL after 8 weeks of regular AC administration than in groups administered SARF and compound 3. Additionally, the administration of AC, SARF, and compound $\mathbf{3}$ caused a significant increase in mice BW. AC and SARF increased BW more significant than compound 3. Nevertheless, to assess the activities of AC, SARF, and compound 3 to reverse alloxan-induced oxidative stress, CAT serum levels were monitored. Thus, the administration of AC, SARF, and compound $\mathbf{3}$ showed significant elevations of CAT serum levels. However, AC showed more increase in CAT serum levels than SARF and compound 3 . In addition, the administration of AC, SARF, and compound 3 attenuated alloxan-induced raised levels of TBARS, a lipid peroxidation marker, and significantly decreased levels of the endogenous antioxidant, glutathione. Thus, it could be suggested that the antioxidant potential of AC, SARF, and compound $\mathbf{3}$ is taking a significant part in reversing alloxan-induced neuropathy, as indicated before with similar compounds [23].

There is substantial evidence, that oxidative damage provoked by free radicals is engaged in the pathogenesis of neurodegenerative diseases, like Parkinson and Alzheimer's disease [24]. Furthermore, ROS (reactive oxygen species) were reported to contribute to diabetes and neuropathic-pain pathogenesis [25-27]. Previous reports utilizing other antinociceptive compounds with similar antioxidant potentials strengthen the findings observed in mice receiving AC, SARF, and compound $3[23,28]$.

Combined with the elevation in oxidative stress, alloxan showed a significant elevation in BGL. Moreover, AC, SARF, and compound 3 showed powerful antidiabetic activity, reversing alloxan-induced hyperglycemia. However, AC showed more powerful antidiabetic activity than its most active fraction (SARF) and constituent (compound 3), indicating that there is an apparent additive effect between the AC constituents potentiating its activity.

After 8 weeks of alloxan-induced diabetes, the mice showed evidence of thermal hyperalgesia $(8.49 \pm 0.19 \mathrm{~S}$ at baseline to $4.80 \pm 0.20 \mathrm{~S}$ in hot plate latency and $5.29 \pm 0.02 \mathrm{~S}$ at baseline to $2.16 \pm 0.02 \mathrm{~S}$ in tail flick latency) and mechanical allodynia $(9.10 \pm 0.20 \mathrm{~g}$ at baseline to $2.55 \pm 0.19 \mathrm{~g}$ using Von Frey filaments), comparable to those illustrated before in literature [12, 20, 29, 30]. We investigated the antinociceptive potentials of AC, SARF, and compound $\mathbf{3}$ against hot plate and tail flick thermal hyperalgesia. Mice that were administered AC, SARF, and compound $\mathbf{3}$ showed significant amelioration of thermal hyperalgesia. Moreover, the highest dose of AC showed more hypoalgesic activity than that of SARF and compound 3. Furthermore, the antinociceptive activities of AC, compound 3, and SARF against mechanical allodynia were monitored utilizing Von Frey filaments. Animals to which AC, SARF, and compound 3 were administered showed a significant amelioration of thermal hyperalgesia. However, the highest dose of AC showed more amelioration of tactile allodynia than those of SARF and compound 3. Thus, AC showed more powerful antinociceptive activity against thermal hyperalgesia and mechanical allodynia than its most active fraction (SARF) and constituent glaucine (3), showing that there is an apparent additive effect between AC constituents potentiating its activity as concluded before in literature [12, 20, 29, 30].
In conclusion, the findings of this work demonstrated that the ethanolic extract of $A$. coronaria herb (AC) and its most active fraction (SARF) showed interesting antihyperglycemic and antinociceptive activities and that its most active constituent was the alkaloid, glaucine (compound 3 ). The results indicate a possible future use of $A C$ in the management of diabetes mellitus and DN. AC might have exerted the antinociceptive effects by the regulation of blood glucose levels and reversing alloxan-induced oxidative stress. Comprehensively, $A$. coronaria herb is a good candidate for further clinical investigation as a complementary therapy with a satisfactory margin of safety for the management of diabetic neuropathy pain.

\section{Materials and Methods}

\section{General}

The protocols and experimental procedures ( $\vee$ Table 1 ) used in this study were conducted abiding the standards of the local animal welfare committee and were reviewed by the Beirut Arab University Institutional Review (IRB; Register Number: 2016A-0031-P-R-108).

\section{A. coronaria herb}

The $A$. coronaria herb was commercially purchased from Ibn El-Nafees herbalists (Beirut, Lebanon). The herb was authenticated by Prof. J. Habib (LU, Lebanon) against an authentic sample, and a reference sample was carefully preserved in the faculty's herbarium (voucher specimen number PS-15-14). The herb was dried on the ground in the shadow and stored under refrigeration $\left(4^{\circ} \mathrm{C}\right)$ until further processing.

\section{A. coronaria extraction protocol}

A. coronaria was extracted with $80 \%$ ethanol by sonication three consecutive times for $72 \mathrm{~h}$ at normal pressure. The extracts were combined and dried utilizing a Buchi rotary evaporator under reduced pressure at a temperature of $40^{\circ} \mathrm{C}$. The dried extract was kept frozen $\left(-30^{\circ} \mathrm{C}\right)$ until the experiment time [20].

\section{Bio-guided fractionation and isolation of A. coronaria active principles}

The dried extract was dissolved in basified water $(\mathrm{NH} 4 \mathrm{OH}, \mathrm{pH} 9.5)$. The filtrate was extracted with chloroform three consecutive times, and the extracts were combined and concentrated. Then the sample was fractionated by analytical column chromatography. RP-silica gel was used as stationary phase and a gradient mobile phase of a mixture of $(A)$ triethylamine $(0.1 \%)$ and $(B)$ acetonitrile was used (starting with $100 \% \mathrm{~A}$, then $60 \% \mathrm{~A}$, and finally $100 \% \mathrm{~B}$ ). About 200 fractions were collected and every fraction was examined for its hypoglycemic and antinociceptive effects. The ${ }^{1} \mathrm{H}$ and ${ }^{13} \mathrm{C}$ NMR spectra of the isolated compounds were measured in $\mathrm{MeOH}-\mathrm{d} 4$ on a Bruker ARX-300 spectrometer. The main active fraction was injected directly into a JASCO RP-HPLC apparatus, after dissolving in the mobile phase. The mobile-phase was formed of a combination of $60 \%$ triethylamine $(0.1 \%$ ) and $40 \%$ acetonitrile at $1 \mathrm{~mL} / \mathrm{min}$ flow rate, utilizing a Merck C-18 endcapped-Lichrospher column ( $250.00 \times 4.60 \mathrm{~mm}$ i.d.; $5.00 \mu \mathrm{M}$ particle size) as stationary-phase, at $40^{\circ} \mathrm{C}$ and $280 \mathrm{~nm}$ [17]. 


\section{Statistical analysis}

The results were measured in terms of the \pm standard error of the mean (S.E.M.). All in vivo results were statistically assessed by oneway analysis of variance (ANOVA), then the Dunnett test, using "OriginPro" statistics program, was done. The $p$-value $\leq 0.05$ was designated as a statistically significant result.

\section{Supporting information}

Details on chemicals, solvents and standards, animals, study design, assessment of oxidative stress markers, and assessment of diabetic neuropathy methods are available as Supporting Information.

\section{Acknowledgments}

The authors would like to thank Mrs. G. Onsy for professional language editing.

\section{Conflict of Interest}

The authors declare no conflict of interest.

\section{References}

[1] Gürdal B, Kültür Ş. An ethnobotanical study of medicinal plants in Marmaris (Muğla, Turkey). J Ethnopharmacol 2013; 146: 113-126

[2] Dhooghe E, Grunewald W, Reheul D, Goetghebeur P, van Labeke MC. Floral characteristics and gametophyte development of Anemone coronaria L. and Ranunculus asiaticus L. (Ranunculaceae). Sci Hortic 2012; 138: 73-80

[3] Laura M, Borghi C, Bobbio V, Allavena A. The effect on the transcriptome of Anemone coronaria following infection with rust (Tranzschelia discolor). PLoS One 2015; 10: e0118565

[4] Saito N, Toki K, Moriyama H, Shigihara A, Honda T. Acylated anthocyanins from the blue-violet flowers of Anemone coronaria. Phytochemistry 2002; 60: 365-373

[5] Toki K, Saito N, Shigihara A, Honda T. Anthocyanins from the scarlet flowers of Anemone coronaria. Phytochemistry 2001; 56: 711-715

[6] Mimaki Y, Watanabe K, Matsuo Y, Sakagami H. Triterpene glycosides from the tubers of Anemone coronaria. Chem Pharm Bull (Tokyo) 2009; 57: 724-729

[7] El Beyrouthy M, Arnold N, Delelis-Dusollier A, Dupont F. Plants used as remedies antirheumatic and antineuralgic in the traditional medicine of Lebanon. J Ethnopharmacol 2008; 120: 315-334

[8] Mimaki Y, Watanabe K, Matsuo Y, Sakagami H. Triterpene Glycosides from the Tubers of Anemone coronaria. Chem Pharm Bull (Tokyo) 2009; 57: 724-729

[9] Acevedo N. The Maillard reaction, Interface between aging, nutrition and metabolism. By Merlin Thomas and Josephine Forbes, editors. Food Res Int 2011; 44: 826

[10] Hartmann N, Neininger MP, Bernhard MK, Syrbe S, Nickel P, Merkenschlager A, Kiess W, Bertsche T, Bertsche A. Use of complementary and alternative medicine (CAM) by parents in their children and adolescents with epilepsy - Prevelance, predictors and parents' assessment. Eur J Paediatr Neurol 2016; 20: 11-19

[11] Maahs DM, West NA, Lawrence JM, Mayer-Davis EJ. Chapter 1: Epidemiology of Type 1 Diabetes. Endocrinol Metab Clin North Am 2010; 39: 481-497
[12] Nomura EC, Rodrigues MR, da Silva CF, Hamm LA, Nascimento AM, de Souza LM, Cipriani TR, Baggio CH, Werner MF. Antinociceptive effects of ethanolic extract from the flowers of Acmella oleracea (L.) R.K. Jansen in mice. J Ethnopharmacol 2013; 150: 583-589

[13] Zhao X, Li XL, Liu X, Wang C, Zhou DS, Ma Q, Zhou WH, Hu ZY. Antinociceptive effects of fisetin against diabetic neuropathic pain in mice: Engagement of antioxidant mechanisms and spinal GABAA receptors. Pharmacol Res 2015; 102: 286-297

[14] Micó JA, Ardid D, Berrocoso E, Eschalier A. Antidepressants and pain. Trends Pharmacol Sci 27: 348-354

[15] Raafat K. Pain diagnosis and management: challenges and opportunities. J Clin Anesth Manag 2016, doi:10.16966/2470-9956.106

[16] Raafat K, Wurglics M, Schubert-Zsilavecz M. Prunella vulgaris L. active components and their hypoglycemic and antinociceptive effects in alloxan-induced diabetic mice. Biomed Pharmacother 2016; 84: 1008-1018

[17] Bogdanov MG, Svinyarov I, Keremedchieva R, Sidjimov A. Ionic liquidsupported solid-liquid extraction of bioactive alkaloids. I. New HPLC method for quantitative determination of glaucine in Glaucium flavum Cr. (Papaveraceae). Separation Purific Technol 2012; 97: 221-227

[18] Howat W], Lewis A, Jones P, Kampf C, Pontén F, van der Loos CM, Gray $\mathrm{N}$, Womack C, Warford A. Antibody validation of immunohistochemistry for biomarker discovery: Recommendations of a consortium of academic and pharmaceutical based histopathology researchers. Methods 2014; 70: 34-38

[19] Anaya-Eugenio GD, Rivero-Cruz I, Rivera-Chávez J, Mata R. Hypoglycemic properties of some preparations and compounds from Artemisia ludoviciana Nutt. J Ethnopharmacol 2014; 155: 416-425

[20] Raafat K, Aboul-Ela M, El-Lakany A. Alloxan-induced diabetic thermal hyperalgesia, prophylaxis and phytotherapeutic effects of Rheum ribes L. in mouse model. Arch Pharm Res advance online publication 26 March 2014 doi:10.1007/s12272-014-0372-y

[21] Bakirel T, Bakirel U, Keles OU, Ulgen SG, Yardibi H. In vivo assessment of antidiabetic and antioxidant activities of rosemary (Rosmarinus officinalis) in alloxan-diabetic rabbits. J Ethnopharmacol 2008; 116: 64-73

[22] Szkudelski T. The mechanism of alloxan and streptozotocin action in B cells of the rat pancreas. Physiol Res 2001; 50: 537-546

[23] Muthuraman A, Diwan V, Jaggi AS, Singh N, Singh D. Ameliorative effects of Ocimum sanctum in sciatic nerve transection-induced neuropathy in rats. J Ethnopharmacol 2008; 120: 56-62

[24] Honda K, Casadesus G, Petersen RB, Perry G, Smith MA. Oxidative stress and redox-active iron in Alzheimer's disease. Ann N Y Acad Sci 2004; 1012: 179-182

[25] Otto M, Bak S, Bach FW, Jensen TS, Sindrup SH. Pain phenomena and possible mechanisms in patients with painful polyneuropathy. Pain 2003; 101: 187-192

[26] Pop-Busui R, Sima A, Stevens M. Diabetic neuropathy and oxidative stress. Diabetes Metab Res Rev 2006; 22: 257-273

[27] Gao X, Kim HK, Chung JM, Chung K. Reactive oxygen species (ROS) are involved in enhancement of NMDA-receptor phosphorylation in animal models of pain. Pain 2007; 131: 262-271

[28] Nishiyama T, Ogawa M. Intrathecal edaravone, a free radical scavenger, is effective on inflammatory-induced pain in rats. Acta Anaesthesiol Scand 2005; 49: 147-151

[29] Raafat K, Samy W. Amelioration of diabetes and painful diabetic neuropathy by Punica granatum L. extract and its spray dried biopolymeric dispersions. Evid Based Complement Alternat Med 2014; 2014: 180495

[30] Raafat KM, Omar AG. Phytotherapeutic activity of curcumol: Isolation, GC-MS identification, and assessing potentials against acute and subchronic hyperglycemia, tactile allodynia, and hyperalgesia. Pharm Biol 2015; 54: 1334-1344 